\title{
The early stage history of Jules Romains' Volpone
}

\author{
Purificación Ribes Traver \\ University of Valencia
}

\begin{abstract}
No other adaptation of Volpone has ever received as enthusiastic a reception as Jules Romains' free version did when it premièred in 1928. It held the stage for over 250 nights and continued to attract large numbers of spectators when taken on tour during the seasons following. The aim of this paper is to uncover the reasons for such overwhelming success by analysing both the theatrical merits of the script and the performing abilities of Charles Dullin's and Charles Baret's ensembles. The information provided by playbills, theatre programmes and critical reviews cast light on the horizon of expectations of their audiences. They make possible an assessment of the ideological approach they favoured as well as of the staging techniques they preferred.
\end{abstract}

KEYWORDS: Romains, Volpone, text, performance.

\section{Introduction}

The aim of this paper $^{1}$ is to uncover the reasons why Jules Romains' French adaptation of Volpone, premièred in November $1928,{ }^{2}$ surpassed any other version of the play in audience appeal. The conclusion that I have reached after analyzing both the printed text and the critics' reactions to its numerous performances is that it fully met the horizon of expectations of his contemporaries. ${ }^{3}$

The tone of Romains' reworking of the text was undoubtedly appropriate to the tastes of his audience, as the observations of most

\footnotetext{
${ }^{1}$ Research for this essay was funded by Project UV-AE-20070217.

${ }^{2}$ It was first staged at the Atelier, Paris, on 23 November 1928.

${ }^{3}$ Hans R. Jauss's “Erwartungshorizont", as defined in Jauss (1970).

(S) ederi 19 (2009): 121-150

https://doi.org/10.34136/sederi.2009.6
} 
theatre critics reveal. The play benefited, moreover, from a tight structure which helped the action progress in a logical way, while keeping the interest of the audience alive. A gallery of unforgettable and resourceful characters was also provided for the delight of spectators. But, as the evidence suggests, the performance would not have achieved the enormous success it did, had it not been staged by a first-rate cast, headed by an expert director. This was precisely what allowed Romains' version of Volpone to hold the Parisian stage for over 250 nights after its première.

\section{Text-centred performance}

Director Charles Dullin, who also played the leading role, offered a spectacle where every single element of the performance setting, costumes, lighting, music- contributed to the actors' enactment of their roles. The text was made fully meaningful, since an experienced ensemble aptly nuanced every aspect of their performance, from body movement to facial gesture, delivery of lines, rhythm and intonation. The perfect conjunction of text and performance ensured a prolonged life of the play on stage: not only did Dullin's Company perform it regularly until 1945, but the comedy enjoyed a successful number of seasons on tour with $\mathrm{Ch}$. Baret's Company.

The play's success was undoubtedly determined by the importance accorded to role-playing. Setting and accessories were at all times subsidiary to it. The schematic setting which André Barsacq devised for the Atelier in 1928 suited the performance so perfectly that Jean-Louis Barrault continued to use it when he staged the play at the Marigny in $1955 .{ }^{4}$ Barrault was one of Dullin's most outstanding disciples and shared his view on the centrality of the performer to a play. ${ }^{5}$ The production which he offered his audience

\footnotetext{
${ }^{4}$ His setting and costumes were valued so highly that Baret's touring company advertised them in playbills and programmes as follows: "Volpone nous est annoncé pour bientôt par les Tournées $\mathrm{Ch}$. Baret avec une interprétation de tout premier ordre et avec des décors, costumes et accessoires absolument semblables à ceux de la création" (Playbill 2.9.1929; 19.11.1929; 19.4.1930; 4.8.1930; "Les Avant-Premières" 8.1.1930, 22.11.1930).

${ }^{5}$ For a more detailed explanation of Barrault's attention to diction, movement and precision of gesture, see Lyons (1967: 415-424).
} 
was, therefore, close in outlook to that of Dullin, and, consequently enjoyed great acceptance, not only in France, but also abroad.

When Barrault took his production to the Winter Garden in New York in 1957, theatre critics underlined the admiration that this company aroused among American theatre-goers. In Gassner's view (1957: 118), they were envious of the Parisians, who had enjoyed Barrault's productions for two decades. Almost thirty years had gone by since Dullin's première, but the key to the play's success still lay in the happy combination of a good script and a responsive and professional cast. $^{6}$

This fact was particularly clear to those American critics who attended the Rooftop production of Volpone that same year. Although the play was then performed in English, they felt that neither the text nor the production could equal that of the French company (Barbour 1957: 261). Curiously enough, the text was not as removed from theirs as one might imagine, although the standard set by Barrault was too high for an amateur company. The text which the Rooftop theatre had staged was Ruth Langner's English translation of Stefan Zweig's free version of the play. And the truth is that Langner's faithful translation of the German adaptation was fully satisfactory. Zweig's version, moreover, had been the point of departure of Romains' own adaptation, and had been successfully

\footnotetext{
${ }^{6}$ This would also account for the success of Tourneur's film of Volpone, released in 1941, whose script was partly written by Romains. It would be misleading, however, to resort to Tourneur's film as a means of illustrating Dullin's 1928 theatrical production at L'Atelier. Even though both artistic products achieved remarkable standards of quality, their differences are too significant to consider them as equivalent. It cannot be ignored that Dullin and Tourneur employed different scripts, a different cast of actors, and, above all, a different artistic language. The theatrical style of filming characteristic of the pre-war period, moreover, had been replaced with a new cinematographic language which was not interchangeable with that of the theatre. The relevance, for example, which Tourneur gives to close-ups as a means of revealing the innermost thoughts of his characters cannot possibly be transferred to a playhouse, whose size removes the effectiveness of these gestures.

Certain similarities, however, seem to relate these accomplished products of the theatrical and filmic media, since both Dullin and Tourneur had to overcome important economic difficulties. Tourneur was particularly heroic since his film was shot under the Nazi occupation at a time when most cinematic activity had ceased in France. But, although his house in Paris had been destroyed by bombs, he continued to edit magnificent films, which, like Volpone, mirrored the political and social tensions of a period when hypocrisy and dishonesty were the rule.
} 
performed all over Europe, starting in Vienna in $1926,{ }^{7}$ and following in Germany and Switzerland soon afterwards. ${ }^{8}$ Translations into different languages soon followed, so that Zweig's version was taken to places as distant as the United States (1928) and Italy (1929).

\section{Romains's adaptation of Volpone}

Although Zweig's free version had the merit of effectively recovering Jonson's comedy for the modern stage, it was still liable to some improvement, particularly in relation to structural coherence and character consistency, as Romains' apt reworking of the text amply shows. His theatrical background included a practical knowledge of the possibilities that a text could offer for performance, as he had been training professional actors with Copeau and Jouvet during the early twenties (cf. Copeau 1974 (1913): 28-30) and was well aware of the importance that structural coherence and character consistency had for a successful performance.

Romains was also aware that the tastes of audiences change depending on their geographical, cultural and ideological background, so that some aspects of Zweig's version that pleased Austrian or German audiences could be valued less positively by French spectators, and vice-versa. Zweig must have shared this viewpoint, and, since he was acquainted with Romains' talent for drama, he did not ask him to render it literally in French, but fully trusted his ability to adapt it for the French stage. That is why, in a letter written in Salzburg in January 10 1929, Zweig told Romains: "J'ai pensé, si cela ne vous intéressait de vous en occuper -je ne dis pas traduire, mais faire librement une adaptation" (Romains 1928b; quoted Rony (1993: 333; my italics). And he showed complete confidence in its successful outcome: "Transformé pour la France par vous, cela pourrait [...] remplir les théâtres deux ans" (Romains 1928b; quoted Rony (1993: 333; my italics).

\footnotetext{
${ }^{7}$ It was premièred at the National Theatre of Vienna (Wiener Burgtheater) on 6 November 1926.

${ }^{8}$ It remained in the repertories of the National Theatres of the largest German towns until 1933, when the Nazi regime banned the play of its Jewish adaptor.
} 
It certainly did, and more than one perceptive critic realized the reason why Romains' version had become so popular. Edmond Jaloux (Temps, 4.12.31), for example, summarized his contribution to the new version as follows: "M. Jules Romains a traduit la pièce de M. Zweig et l'a adaptée au ton de Paris." And, although he pointed out the changes which Zweig had introduced in order to modernize Jonson's comedy, “M. Stefan Zweig a recréé la pièce au goût des esprits modernes, ajouté un personnage et modifié le dénouement" (my italics), he suggested that French audiences required further modifications.

Zweig had removed the play's secondary plot in order to make it advance at a faster pace. All the characters from this plot disappeared except for Lady Would-Be, whom Zweig transformed into the Courtesan Canina. Like Jonson's character, she was forward and determined to have a share in Volpone's will. She tried to achieve her end by offering him her personal services for nothing, in the hope of becoming his legal wife -and, soon afterwards, his widow and sole heir. In the end she gets a consolation prize from Zweig's winning hero, Mosca, who finally inherits Volpone's estate. He buys her a husband to make the child she is expecting legitimate.

Zweig's version, unlike Jonson's, does not end in the stern punishment of all the greedy characters, but only in Volpone's exile from Venice. In the end, Mosca, who has discovered how useful a sudden stroke of generosity can be to make sure that nobody declares Volpone's testament invalid, turns into an openhanded host who gives the greedy characters some crumbs from Volpone's trencher in the form of gifts and an invitation to supper at his new mansion.

Romains had expressed confidence in his own capacity to offer a version of Volpone that could meet the needs and tastes of his countrymen. In Correspondance he had rhetorically asked: "Sommesnous incapables, en France, de ce travail après tout facile et subalterne qui consiste a's'approprier discrètement un chef d'oeuvre?" And that is precisely what he did, for, instead of completely depending on Zweig's version for his own, he also turned to Jonson for inspiration, particularly in connection with the

9 Jules Romains, "Comment est née cette version de Volpone," Correspondance 2 (November 1928), quoted in Hélène Henry (1960: 199). 
tone he chose for his adaptation. His approach to Jonson's hypotext (Cf. Genette 1987), however, was never servile, because, in his view, "[Volpone] ne peut revivre pour nous qu'à condition d'être remanié profondément, ou pour mieux dire, repensé et refait. ${ }^{\prime 10}$

\section{Romains' méchant social vs. Zweig's méchant physiologique}

A comparison between the published version of Zweig's (1926) and Romains' (1928) adaptations immediately reveals an essential difference of tone in both texts, for, whereas Zweig creates a gloomy and oppressive atmosphere with sadistic characters who delight in torturing others, Romains chooses a more amiable tone for his version. His characters still retain the necessary malice for the satirical approach of the play to be effectively conveyed, but he removes the excess of wickedness which he perhaps felt interferes with the happy ending which both Zweig and himself chose for their versions. Another possible reason behind his decision to create more humane characters is that it is closer to his own perception of the world. Romains' description of Volpone in "Avant-Première" subtly points to this essential difference of approach between Zweig's version and his own, although he never specifies that he is describing the character created by his Austrian friend. In Romains' own words:

Volpone est [...] le méchant complexe, contrasté, tourmenté, méchant par intelligence, méchant par expérience [...] parce qu'il porte dans le dernier fond de son coeur [...] un certain idéal de l'homme et de la vie, un certain rêve de pureté, de générosité, de bonté, que toute son expérience des hommes est venue démentir. (Paris-Soir: 23.11.1928; my italics)

And he then makes clear what traits his character does not have. Anybody acquainted with Zweig's lieblose Komödie can find here a shrewd description of his character:

[Volpone n'est pas] le méchant physiologique, le monstre pur, qui n'intéresse que le psychiatre, qui reste hors du domaine de la grande comédie, mais le méchant social [...] l'homme qui provoque la naissance autour de lui, la convergence vers lui de passions viles. (Paris-Soir: 23.11.1928; my italics)

\footnotetext{
${ }^{10}$ Romains, "Comment est née cette version de Volpone," quoted in Henry (1960: 199).
} 
It is precisely Volpone's ability to awaken men's basest instincts that reviewers of Romains' version repeatedly highlight. René Salomé, for example, describes him as

un avare [...] qui prend un malin, un démoniaque plaisir à exaspérer la convoitise des trois voisins [...] l'avilissement d'autrui l'intéresse et l'amuse [...] son esprit curieux et pervers se plaît à sonder la malice humaine. (Études 1929: 343; my italics)

This idea is also emphasized by D'Houville, from Le Figaro, when he says: "Autant que manier ses objets précieux et cachés, il [Volpone] lui plait de jouer de la bassesse humaine" (3.12.1928: 2; my italics). ${ }^{11}$

As Oliver Rony (1993: 574) aptly observes, the topic which Romains dealt with in Volpone was akin to his personal preferences, ${ }^{12}$ and it offered him the possibility of condemning human rapacity:

Jules Romains, disposant d'un sujet miraculeusement accordé à son univers personnel, poursuit là la même enteprise de dénonciation que dans ses pièces précédents [...] une vision désabusée d'un monde mené par les passions [...] par sa fascination pour la possession des biens au détriment de toute générosité désintéressée (Rony 1993: 349).

It can be easily perceived that his awareness of human greediness would be particularly acute around the time when this piece was staged. The French economy was undergoing a miraculous recovery under Poincaré after seven years of post-war depression. The situation was being rapidly reversed, to the substantial benefit of a few who were quick to take advantage of the favourable circumstances. ${ }^{13}$

${ }^{11}$ Baret's Touring Company had taken special care to advertise this feature of Volpone's personality. In their Summer programme of 1929, they said: "Volpone [...] s'amuse, secondé par son valet et conseiller, Mosca, à augmenter sa richesse au détriment de ses amis trop cupides," and in November 1929, they specified that he liked to "bafouer la cupidité des gens qui l'entournent" (Muller 1929-1930; 1930-1931).

${ }^{12}$ It would reappear in different plays throughout his career. As Oliver Rony points out when he refers to L'An Mil, premièred on 13 March 1947, "Carcaille, nouveau Volpone, déploie une belle rhétorique pour faire admettre ses impostures et rejoint par là une gallerie où figurent [...] ces hommes cyniques que le théâtre de Jules Romains privilégie depuis plus de vingt ans" (1993: 574).

${ }^{13}$ Some novelists had tellingly echoed this painful situation which bears thematic connections to Volpone. As Catharine Savage comments on Roland Dorgelès' Le Réveil 
Although perhaps less markedly than in France, this tendency was generalized in post-war Europe during the second half of the decade. Even Germany, although overwhelmed by its debts, experienced a spectacular recovery with the financial aid of the United States. A fever for consumption and speculation extended throughout Europe, and, especially, the United States, which would lead to an economic depression sooner than expected. In the same way that Volpone's greed would deprive him of all that he had got by obscure means, risky speculation would bring about the loss of great fortunes which had been swiftly made. Zweig left an eloquent depiction of man's natural inclination to greed both in his version of Volpone and in his Die Welt von Gestern, where he gave a telling description of the rapacity of his fellow men: "Wer zu bestechen wußte, kam vorwärts; wer spekulierte, profitierte [...] es gab keine Tugend als die einzige: geschick, geschmeidig, bedenkenlos zu sein und dem jagendem Roß auf den Rücken zu springen, statt sich von ihm zertrampeln zu lassen" (2007 (1942): 333).

As in previous pieces, Romains wanted his audience to be aware of the satirical intent of his version, and critics attending different performances seem to have perceived this satirical approach. This was the case of Bidou (1929), who declared that in Volpone "Il [Romains] a plutôt donné une moralité à une comédie," an idea which had already been expressed by René Salomé, according to whom, "La satire est manifeste et l'intention morale n'est pas voilée" (1929: 345).

This idea was emphasized by the Baret company (2.2.1929) when they announced in their programme that their aim was "le divertir tout en le forçant à réfléchir, à s'élever: castigat ridendo mores." Whether consciously or not, they were resorting to the same paratextual device as Jonson had in his own day to persuade their audience of the comedy's morality. He then echoed Horace's maxim docere et delectare in the Prologue to his play:

This we were bid to credit from our poet,

des Morts, published in 1923, it is "a novel concerning the post-war rebuilding of a ruined village near Soissons, [which] provides a vivid picture of war's effects in rural France. As if four years of German presence did not suffice, reconstruction brings new scourges - profiteers who grow rich on development schemes and swindle the gullible: [...] violation of laws meant to protect the vulnerable; meanness and dishonesty at all levels" (2005: 179; my italics). 
Whose true scope if you would know it,

In all his poems still hath been this measure,

To mix profit with your pleasure. (I.1.5-8)

Jonson's audiences were allowed to profit from the moral message of the play in a very pleasurable way. Aware that he was going against the laws of comedy, which required a happy ending, he justified his choice in the Epistle addressed to the universities of Oxford and Cambridge, stating that he had looked back to the Classics for a model which could justify the harshness of his didactic ending:

And though my catastrophe may, in the strict rigour of comic law, meet with censure, as turning back to my promise; I desire the learned, and charitable critic to have so much faith in me, to think it was done of industry [...] But my special aim being to put the snaffle in their mouths that cry out, we never punish vice in our interludes \&c., I took the more liberty; though not without some lines of example drawn even in the ancients themselves, the goings out of whose comedies are not always joyful, but oft-times, the bawds, the servants, the rivals, yea, and the masters are mulcted: and fitly, it being the office of a comic-Poet to imitate justice, and instruct to life. (11. 119-133)

When Zweig rewrote the play for his audience he must have perceived a certain incongruity between the sympathy which these witty characters aroused in their audience and the stern tone of the punishment which they received. He probably realized that one reason why audiences sympathized with their tricks was that the rogues' "victims" were mainly greedy and despicable characters who deserved to be gulled. That is perhaps why Zweig provided the play with a more amiable ending where Volpone escapes Venice and returns to his own family, and Mosca is left with his fortune instead of being sent to the galleys. The problem, however, lies in the fact that Zweig did not limit his changes to the ending of the play, but modified the features of his characters, all of whom are moved by an inner need to inflict pain on others. The result of this radical transformation is a very dark comedy from which no one would expect a happy ending. ${ }^{14}$

\footnotetext{
${ }^{14}$ However, even Herford and Simpson (1925-1952 v. 9: 207-208) seem to have been deceived by the tone of Zweig's adaptation, and particularly by the character of Mosca, whose tender feelings and generosity they do not question. Perhaps the reason for this assessment lies in their second-hand knowledge of the German version. Other
} 
A dramatist as perceptive as Romains was quick to realize the need to reduce the sadistic impulses that move many of the characters -especially Volpone- in order to make the ending more coherent with the rest of the play. As a result of his changes, his characters still keep Jonson's lively malice and their ability to dupe greedy victims, but they are deprived of superfluous wickedness.

Although Romains softened Zweig's harshness of tone, he left enough to make the piece pungent. An overview of the reactions which his version provoked among French audiences makes clear that he carefully calculated how spicy his piece should be. He was aware that malice and violence for their own sake did not suit their tastes -as they did not his own either-but, at the same time, he also knew that his spectators were ready to enjoy a realistic portrayal of humans' basest instincts, especially if done with intelligence and wit. That is probably why critics reviewing his Nice première celebrated its "truculences joyeuses" (Éclaireur 10.1.1930).

\section{The critical reception of Romains' version}

The descriptions that some reviewers make of the performances lead us to think that Romains' version was staged with very few cuts because he must have felt that all the passages from the text were suitable for public performance, even those which the critics described as "horrifying". Reviews offer summaries and even quotations from the play which illustrate the tone of those scenes. When D'Houville refers to the sentence pronounced on Volpone at the end of the play, he specifies that "les affreuses [...] feront condamner son [Volpone's] pseudo cadavre à la potence" (Figaro 3.12.1928: 2; my italics). Although Romains removed from his version Zweig's allusion to the nailing of Volpone's tongue to the gallows after his dead body had been hanged, there was still enough to move the audience.

Bidou also gave a detailed summary of how Corvino tried to bring Volpone's suffering to a swift end: "Le gredin Corvino, amer et jaloux, apporte trois cents sequins et une petite fiole d'une certaine

critics such as D. McPherson (1973: 82) and Forsyth (1981: 622) also praise the amiable tone of Zweig's adaptation, probably because its happy ending leads them to ignore that the last-minute change is superficial. 
drogue qui calme, qui calme enormement" (Bidou 1929). That makes the audience understand why Volpone hates him and his friends so deeply. Bidou this time quotes the exact words, so as to offer an accurate picture of the character: "Un beau jour, je tombe malade [...] malade de mourir [...] et la danse commence au tour de mon or [...] Comme ils m'aiment! [...] Ah! Que j'aimerais les écraser tous ces cobras" (Bidou 1929; my italics). As often in his version, Romains has omitted long passages where Volpone openly expresses his hate of mankind. He leaves just enough to make the character credible but removes all the traits that belong to a pathological personality. The general tone of the play, however, is often perceived as "deliciously shocking." Edmond Jaloux, for example, recalled that spectators attending the play had been "éblouis par la vie violente et bariolée [de Volpone]" (1931). This figure was so highly regarded that it minimized the negative effects of his devilish nature, as René Salomé declared: "Si Volpone est un monstre satanique, c'est un monstre vivant, animé, tumultueux"(1929: 344; my italics). And, of all his qualities, it was his quickness of mind that they valued most, even if he did not adhere to any moral code. Gabriel Davin de Champclos, for example, praised Janvier for having performed "avec [...] talent sûr et désinvolte, les âpres canailleries de Volpone" (1930). This positive assessment of Janvier's performance in November 1930 is in keeping with the appraisal that the critic of Éclaireur had made in January 1930 when the play was performed in Nice. He then remarked that Volpone, as played by Janvier, was "plein de finesse et veuf de scruples" (Davin de Champclos 1930).

Mosca's resourcefulness and imagination was similarly esteemed. His lack of scruples did not seem to interfere with a positive appraisal of the character, as de Champclos' assessment reveals when he describes Sablot's performance in Nice as "amusant et amoral" and delightedly recounts that Mosca "amorce une canaillerie dans une piruette" (1930). Henry appears to be similarly fascinated by his quickness of mind when he underlines that Mosca "était agile et suavement perfide" (Henry 1960: 200; my italics).

Some critics have gone so far as to point out Mosca's role as moraliser in the play. But even those who recall his aptness at punishing the covetous birds of prey (Corbaccio, Corvino, Voltore) have at the same time stressed the delight he takes in teasing them. Thus, in Bidou's view, "Mosca [est] dilettante en fourberie et coquin 
par plaisir, mais en même temps moralisateur et vengeur" (1929; my italics). He then explains his active part in inflicting punishment upon the greedy characters who covet Volpone's gold.

Critics, again, are responsive to the change in outlook that Romains' version presented as compared with Zweig's. He had transformed an ill-willed Volpone into a malicious character who aimed at punishing the avarice of his suitors. This is clearly explained in the plot summary which was included in the programmes available at the Atelier in November 1928. It recounted how Volpone revolted against the baseness of his dupes: "La bassesse de ses dupes l'oecoeure" because "Des voisins, bassement avides, cònvoitent sa succession" (Programme pour Volpone 1928; my italics). And he mentions how he conceived the idea of punishing them: "Il voudrait les punir encore davantage leur bassesse" with Mosca's help; "Il charge Mosca d'inventer spécialment contre Corvino et Corbaccio une roverie vengereusse" (1928; my italics). Mosca seems to have accepted his errand so willingly that Bidou (Feuilleton du Journal des Débats 26.8.1929) makes him fully responsible for the scheme: "Et ce Mosca décide de châtier le vieux Corbaccio [...] il exercera de même sa justice sur l'affreux Corvino. ${ }^{15}$ The theatre programme for the Atelier (23.11.1928) then draws attention to the means which Mosca employs to bring about his vengeance: "La courtisane Canina, qui projette de se faire épouser par Volpone, va fournir sans s'en douter à Mosca le moyen de manoeuvrer l'usurier et le marchand.“

This summary indirectly highlights the importance assigned to structural coherence in Romains' version. In this case it offers a clear motivation for the presence of a character that was absent from Jonson's play but included in Zweig's reworking. Romains justified Canina's presence in the play and modified the character accordingly. Her appeal poses a serious threat to Corbaccio and Corvino, because she intends to marry Volpone. Mosca asks her to visit her competitors and ask them to attend her wedding as witnesses. Her seductive manners convince them that Volpone can be easily persuaded into marrying her, thus thwarting their hopes of inheriting his fortune. Mosca takes advantage of that fear and urges them to tempt Volpone with more valuable presents. Corbaccio then

\footnotetext{
${ }^{15}$ Silvio D'Amico (1930) also realized Mosca's new relevance in Romains' version, "facendolo divenire, di collaboratore che era, Deus ex machina e re del intrigo."
} 
hurries to name Volpone his heir, and Corvino offers his own wife for Volpone's comfort.

Reviews of the performances reveal that Canina played her role convincingly before an admiring audience. Unlike in Austria, no voice was heard regretting her forwardness or indecent behaviour. ${ }^{16}$ It must be born in mind that Austria -and Vienna in particular- was well known for its defence of traditional values. This was particularly noticeable among the usual audience of its Burgtheater, where Zweig's Volpone was premièred. ${ }^{17}$ This attitude would prevent outstanding composers, playwrights and painters alike from exhibiting their work in Vienna. Thus, in 1905 Strauss's operatic version of Salome would be banned from the stage on grounds of its immorality (it would be successfully performed in Berlin and in ten other German opera houses soon afterwards) (Watson 2002: 68). ${ }^{18}$ As in the case of Strauss's Salome, German audiences -unlike their Austrian counterparts- found no fault with Canina's presumed forwardness and immorality. This came as no surprise to their European contemporaries, who were aware of the atmosphere of unrestrained libertinism which had made Berlin famous after World War I. ${ }^{19}$

${ }^{16}$ See Wittner (1927: 20-22); Felusich (1926); B. (1926); Frank (1926). For a more detailed explanation, see Ribes (2007: 66-69).

${ }^{17}$ As Michael Steinberg recalls, "The Burgtheater was the neo-baroque court theatre in Vienna. The neo-baroque becomes the Austrian historicist-conservative phenomenon par excellence" (2000: 2).

18 University professors would not prove more open-minded, as would be demonstrated by their airy reaction to what they deemed the perverse depiction of female nature in the paintings which the Faculty of Philosophy commissioned Gustav Klimt to complete in 1900 (Watson 2002: 48).

${ }^{19}$ As Zweig remarks, "Alle Werte waren verändert und nicht nur im Materiellen [...] Was wir in Österreich gesehen, erwies sich nur als mildes und schüchternes Vorspiel dieses Hexensabbats, denn die Deutschen brachten ihre ganze Vehemenz und Systematik in die Perversion [...] Selbst das Rom des Sueton hat keine solche Orgien gekannt wie die Berliner Transvestiten-bälle [...] Eine Art Irrsinn ergriff im Sturz aller Werte gerade die bürgerlichen, in ihrer Ordnung bisher unerschütterlichen Kreise" (2007 (1942): 356-357).

In Walter Laqueur's view (Weimar: une histoire culturelle de l'Allemagne des anées vingt. 1978: 300, qtd. Nouschi 1996: 115), the disenchantment which seized Germany after the armed conflict was the cause of these excesses: "Berlin became the European capital of sensuous enjoyment. Mutilated, ruined and the victim of a permanent economic crisis, Germany only thought of enjoying itself." 
Unlike in Austria, French critics unanimously praise the part of Canina, which most actresses seem to have performed admirably. This must have been the case of Mlle. Hosptein, who, according to D'Houville (1928: 2), played at the Atelier "une bizarre Canina, très inspirée" and Mme. Darmont, who also shined in Bordeaux, "méritent les plus vifs compliments," as the review in Comedia (1930) reads. If Mme. Darmont was praised as "charmante", Mlle. Madge Derny must have caused a commotion at the Palais de la Méditerranée in Nice. The costume Barsacq devised for the première left the legs of the courtisan in full view of the audience, but critics were not as explicit as de Champclos when he expressed his profound admiration for Mlle. Derny's charms: "Le rôle de la courtisane Canina donne a Mlle. Madge Derny l'occasion d'exhiber a la salle conquise la plus affriolante paire de jambes nues qui ait jamais illuminé un paysage vénitien -ou français" (Davin de Champclos 1930; my italics).

But it was not only Canina's legs that were a source of admiration, since Titayna (Elizabeth Sauvy) (1929) dared emphasize the physical beauty of Daniel Lecourtois, who had played Mosca at the Atelier. His pleasant appearance was linked to his ability to dupe others, and, according to her, determined his lucky end: "[Daniel Lecourtois] prête au vice plaisant et facile un visage agréable et des jambes bien faites [...] Le rideau tombe sur la joie générale à voir échouer la fortune entre les mains d'un si charmant garçon."

\section{Audiences at the Burgtheater and L'Atelier compared}

It may be illustrative to recall the contrasting atmospheres of Paris and Vienna at the turn of the century to appreciate the different degrees of freedom which artists of any type could dream of enjoying in these contrasting milieus. Whereas Paris was open to any new tendency and offered young artists the possibility of exhibiting their work -no matter how unconventional it might be- Vienna systematically banned any work of art which might go against its stern morality. That is why paintings showing the abject world of 
brothels multiplied in Paris at the beginning of the century whereas the depiction of sensuality was prohibited in Vienna. ${ }^{20}$

Even though the status of Vienna's national Burgtheater and the Atelier in Paris were substantially different, they nevertheless reflected the prevalent atmosphere of their respective countries. L'Atelier was a modest playhouse which only became well-known after 1922, when Charles Dullin took up its direction and replaced its commercial repertoire with intellectually demanding pieces. But, although the theatrical traditions of both theatres were different, their performance of classical plays during the 1920s shared a number of interesting features: both were persuaded that the classics could only be performed if properly updated and both were acutely aware of the importance of natural and polished diction. It cannot be ignored, however, that in spite of the high artistic standard achieved by the Atelier, productions at the Burgtheater were more lavish and its audience more conservative, which partly explains the different choices made by the theatre directors as well as the different reception received by their plays.

A playwright as experienced as Romains would not have ignored the tastes of his countrymen. He knew how much they appreciated beauty, and how much they admired good-looking actors and actresses on stage. He was also aware of their tolerant attitude towards scenes which could shock more squeamish audiences. That is why he did not deem it necessary to remove any of those passages which Austrian critics labelled as indecorous or offensive.

However, this approach differed radically from his handling of violence. A couple of examples may suffice to illustrate how much the horizon of expectations of French audiences diverged from those of Austrian theatre-goers in these matters. A comparison between the promptbook which was used for the Burgtheater première in Vienna and Romains' printed version of the play reveals that Romains did not translate any of the passages which were removed from the 1926 performance, but even omitted some which had been retained in Vienna, whereas he rendered in French every single line

${ }^{20}$ For example, erotic paintings such as Picasso's Demoiselles d'Avignon (1907) or Matisse's Bonheur de vivre (1906) could be freely contemplated in Paris while the work of Klimt often met with opposition in Vienna. 
which the Austrian promptbook deleted because it could be deemed indecorous.

Volpone's terrified description of torture, for example, was softened for performance at the Burgtheater, and Romains must have thought that the description was still too upsetting, because his version further tempers it. In Zweig, Volpone exclaims:

Nein... ich gehe nicht zum Tribunal... ich weiß, wie sie inquirieren... die Folter... der Strappado... hab's einmal gesehen, wie sie die Winden aufgezogen, wie's da knackte und knirschte in den zerbrochenen Gelenken... die Daumschrauben, die Zangen, die glühenden Zangen an den Nägeln... wie es pestete von verbranntem Fleisch, uh, uh... nein, ich gehe nicht... ${ }^{21}$ (1926b: 52; my italics)

The Burgtheater promptbook reduces it to:

Nein... ich gehe nicht zum Tribunal... ich wei $\beta$, wie sie inquirieren... die Folter... der Strappado... hab's einmal gesehen, wie's da knackte und knirschte in den zerbrochenen Gelenken... wie es pestete von verbranntem Fleisch, uh, uh... nein, ich gehe nicht... (Zweig 1926b: 52)

And Romains leaves it as:

Non. Je ne vais pas au tribunal... Je sais comment ils donnent la question... le chevalet, l'estrapade... J'ai vu ça, une fois... (1928: 143; my italics)

Corvino's threatening words to his wife, after Mosca makes him jealous by hinting at her flirtation with Venetian citizens, seems to

\footnotetext{
${ }^{21}$ A look at the Jonsonian passage which inspired Zweig's scene reveals the thorough transformation which it had undergone in his hands. In Jonson it is Voltore who speaks these lines when ironically mentioning these types of torture to the judges as a means of proving Volpone's innocence. The Venetian Magnifico had been brought before the Court of Justice and lay motionless while Voltore resorted to this rhetorical device as a means of proving the slanderous nature of Bonario's accusation. He sardonically tells them: "The testimony comes, that will convince, / And put to utter dumbness their bold tongues./ See, grave fathers, here's the ravisher [...] / [...] do you not think,/ These limbs should affect venery? / [...] / Perhaps, he doth dissemble? / [...] / Would you ha' him tortured? [...] / Best try him, then, with goads, or burning irons; / Put him to the strappado: I have heard, I The rack hath cured the gout, faith, give it him, I And help him of a malady, be courteous. / [...] I would ask, / With leave of your grave fatherhoods, if their plot / Have any face, or colour like to truth?" (IV.vi.30-45; my italics).
}

In Zweig's version, however, it is Volpone himself who truly fears that the Court of Justice may impose these kinds of torture upon him for his past crimes. 
have bothered Austrian and French audiences in different ways, since Romains' omissions refer to physical and verbal violence whereas the Burgtheater only deletes potentially indecorous expressions. $^{22}$ Austrian audiences therefore heard the following dialogue:

Corvino: Wann hast du Mosca zum letzten Male gesehen?

Colomba: O weh, Ihr tut mir weh! Ich kenne ja gar keinen Mosca.

Corvino: [...] Noch einmal, wenn ich das Fenster offen finde, zerprügle ich dir alle Knochen. (Zweig 1926b: 28; my italics).

French audiences were offered a different picture of the couple:

Corvino: Quand as-tu vu Mosca pour la dernière fois?

Colomba: Mosca? Quel Mosca?

Corvino: [...] Pas de fenêtres sur la rue. Tu pourras prendre l'air à ton aise! Et je te ferai surveiller par des eunuques. (Romains 1928: 73; my italics)

Similarly, Romains' version keeps the account which Volpone's servants gave of Canina's nightly visit to Volpone, while the Burgtheater cut it. Whereas spectators at the Burgtheater simply heard "[Der erste Diener]: Vorgestern war erst diese Canina da, die ganze Nacht" (Zweig 1926b: 5; my italics), French audiences were offered further details of her visit:

[Premier Serviteur]: Avant-hier encore, la Canina a passé la nuit ici. Toute la nuit, ils ont fait danser le lit au-dessus de ma tête. Il fallait entendre craquer le plancher. Pour arriver à m'endormir, je me suis fourré les oreilles sous ma couverture. (Romains 1928: 12; my italics)

\footnotetext{
22 The Viennesse authorities had traditionally shown great care to prevent the exposure of their ladies to shocking words or expressions. That extreme sensitivity, however, seems to have been perfectly compatible with the quick expansion of a social Darwinism which fostered anti-Semitism at a time when 150,000 Jews were living in Vienna. It was the time when Hitler's Mein Kampf had just gone to press, and Zweig -himself a Jew- knew that an overwhelming majority of Austrians shared Hitler's viewpoint that Jews were an inferior race which should be kept at bay. This is probably the reason why Stefan Zweig's teasing allusion to the need that all Jews be burnt was not removed for performance at the Burgtheater. As he sadly anticipated, few of those sensitive ladies attending Volpone would show any discomfiture at Corvino's enraged exclamation when he was told that a Jewish doctor had given Volpone a drug which prevented him from dying: " [Corvino] Sag' ich's nicht immer, man soll sie brennen und austreiben, diese verdammten Juden! Überall müssen sie sich einmengen!" (Zweig 1926: 30; my italics).
} 
Similarly, Romains did not suppress the reasons that Canina gave Mosca for seeking marriage with Volpone, even though the Burgtheater had given a shortened version of the scene. While Austrian audiences were offered the following report, "[Canina]: Aber siehst du, wenn man so seine zwölf Jahre immer andere hat, da dacht' ich mir, versuchst es einmal mit einem Mann" (Zweig 1926b: 26), Romains thought his spectators would appreciate a fuller explanation:

[Canina]: Eh bien, vois-tu quand on en a toujours changé depuis l'âge de douze ans, chaque nuit un nouveau -et ils vous demandent, et ils vous disent, et ils vous font tous la même chose-alors, ça devient ennuyeux aussi. Je voudrais essayer maintenant avec un seul. (Romains 1928: 64-65; my italics)

The same happens with Mosca's description of the qualities which Canina's future husband possesses. While the Vienna performance simply alluded to his nationality and family names, and was careful to omit Zweig's specification of the candidate's amorous preferences, Romains offers his audience a complete description of the Spanish gentleman:

[Mosca]: Dir kauf' ich einen Mann; kenn' einen Schmarotzer, ist Spanier, hat einen Namen so lang wie der Kanal Grande, sieben Vornamen, neun Zunamen [und hält's nur mit Männern. Den kauf' ich dir, der läßt dich in Frieden bei Tag und Nacht]. (Zweig 1926b: 83; my italics)

Similarly, Romains sees no reason to omit: "Il ne fait la chose qu'avec les hommes. Je te l'achète. Il te laissera tranquille nuit et jour" (Romains 1928: 210; my italics).

On one occasion Romains' confidence in the audience's positive reaction to his text leads him to modify a remark that Mosca makes regarding the proper use of gold. In Zweig's text, he underlines how necessary the existence of spendthrifts is for prostitutes to earn their living: "Wären wir nicht, [...] die Huren müßten's aus Liebe tun" (Zweig 1926b: 40). Although the Burgtheater omits the whole explanation, Romains amplifies it by suggesting alternative means of subsistence: "Sans nous, [...] les catins seraient obligés de faire l'amour entre elles" (Romains 1928: 112; my italics). 


\section{Romains' text and provincial audiences}

The details these theatrical programmes highlight to advertise the play similarly point to a tolerant audience. That is why Baret's Company openly refers to Canina's means of persuading Volpone to marry her: "La belle Canina, beauté professionelle de Venise. Elle voudrait épouser Volpone in extremis, et lui offre ce qu'elle a, ellemême, et gratis, faveur exceptionnelle!" (Muller 1929). The passages highlighted by reviewers further support this hypothesis. Bidou, for example, quotes Volpone's allusion to the power that gold has to entice women: "Laisse-les [les ducats] reluire en paix. Les gens viendront tout offrir d'eux-mêmes. Tu verras femmes ramper vers ton lit“ (1929).

As mentioned earlier, no cuts were deemed necessary when the production was taken on tour because no passage was considered unfit for provincial audiences. The situation is slightly different with regard to the representation of violence. That is why playbills and programmes occasionally make the following warning: "cette oeuvre truculent ne s'adresse pas précisément aux jeunes filles / jeunes personnes don't 'on coupe le pain en tartines" (Playbill 1929b). This last observation minimizes the potential danger of these scenes, since it does not find fault with the production but with the immature minds of youngsters. The warning, moreover, does not seem to have been accompanied by strict measures to control admittance to the playhouse, since, although it informs the playgoer that this spectacle is not included in the season ticket to which they have subscribed, ${ }^{23}$ they nevertheless are offered the possibility of keeping their usual seat at the theatre. ${ }^{24}$

This situation shows, once more, that Romains was adept at calculating what both his Parisian and provincial audiences were willing to entertain. He could anticipate their delight in malicious and witty humour, and, as reviews reveal, he seems to have included enough to please his spectators. This, at least, is the impression that one gets when reading the review written by A.B.

\footnotetext{
23 "Volpone n'est pas un spectacle pour les jeunes filles et pour cette raison, il a été retiré de l'abonnement" (Playbill 1930a).

24 “Cependant les Abonnés qui désideront y assister pourront retenir leurs places habituelles avant l'ouverture de la location en bénéficiant des mêmes avantages" (Playbill 1930a).
} 
for the Vie Bordelaise on August 4, 1930. It praises the setting which Barsacq created for the Atelier because it allowed the attention of the spectators to concentrate on the text:

Les décors stylisés sont nets, frappants. Quand le régard en a été ébloui, els demeurent ensuite au second plan. C'est ainsi qu'a Volpone, après l'èclat de leur présentation, ils se sont comme éffacés davant les mots, où la truculence même est geniale. (A.B. 1930)

Although reviewing a provincial performance, A.B. once more praises the harsh tone of the play which the simple setting highlights. His assessment reveals that audiences and critics perceived this play as highly enjoyable rather than dangerous.

The universality of its subject matter, moreover, made it appealing to a wide audience, as advertised at "Les AvantPremières. Palais de la Méditerranée, Nice": "Par son sujet, touche le fond de l'humanité et intéresse tous les publics" (22.11.1930; my italics). And, as the playbill anticipated, "séduira également la foule et les lettrés" (Playbill 1930a; my italics). Romains' version, which benefitted from an attractive subject matter, found the exact tone, since, as L'Éclaireur (22.11.1930; my italics) reads, "c'est écrit dans une langue á la fois éticelante et directe." It also offered a tight and varied structure which succeeded in holding the attention of the audience: "L'histoire est originale, attachante, pleine de coups de théâtre, et de rebondissements" (Les Avant Premières 193ob; my italics).

\section{The international reception of Romains' version}

An Italian translator of dramatic texts as perceptive as Mario Bellotti was quick to realize how much Romains had improved on Zweig's previous version. In his view, no further changes were needed for its international success: "A mon modeste avis, le Volpone Zweig-Romains est le plus parfait et le plus digne d'être joue -fidêlement traduï-dans tous les pays"(1929; my italics).

As evidence had amply proved, it was bound to succeed anywhere provided it was aptly performed. This is what happened in Brussels when it was staged at the Theâtre du Parc by the Company of the famous Belgian actor M. Gournat. The favourable reaction which G.R., from Indépendance Belge, describes resembles 
that of French audiences: "La salle réagit, amusée par les boutades, les traits satiriques, la verdeur du langage, des personnages qui vivaient sur la scène" (1929). Like French spectators, they appreciated its harsh tone, which they deemed suitable to its subject matter. They found the play an "âpre et puissante comédie [...] extrêmement amusante, non sans ouvrir, sur l'humaine nature, de ces perspectives narquoisement véristes à la Molière" (G.R. 1929).

Their perception of Canina was surprisingly close to that of French spectators. Unlike Austrians, Belgians seem to have enjoyed the part. G.R., when commenting on Mlle. Flore Mahieu's performance, praised "sa grace mutine, son jeu tendrement enveloppant, sa jeune et nerveuse beauté" (G.R. 1929). As pictures from the programme reveal, producers anticipated a favourable reception of the part. That is why they included in it a photograph of Mlle. Mahieu in a dress that allowed full contemplation of her legs. A note was placed underneath which tried to draw attention to the spiciness of the character: "Canina (Mlle. Flore Mahieu) dans une des scènes le plus piquantes de Volpone" (Programme pour Volpone 28.12.1929; my italics).

Such an approach to the role of Canina, however, would have been unimaginable in neighbouring Spain. As graphic evidence from the performances at the Beatriz reveal, the costume worn by Srta. Monero left only her shoes in view. The front part of her long skirt had been conveniently lengthened for a more modest presentation of the character (Calvo 1930). The lines Canina spoke had also been adapted to the requirements of Spanish audiences -and censors. That is why the translation Precioso and Sánchez Guerra (1930) made of Romains' French version carefully removed all those expressions which could be deemed improper for the stage (Ribes 2006: 265-272). Some French reviewers would regret these cuts which, in their view, diminished the satirical force of the play. As Jean de Joannis aptly observes, "Les traducteurs MM. A. Precioso et Sánchez Guerra ont cru utile d'édulcorer le texte et d'en faire disparaitre des expressions don't la crudité risqué de déplaire." And he adds: "peut-être la satire perd-elle ainsi de sa force et de sa saveur" (1930; my italics).

The truth is that Spanish spectators attending the première in Madrid ${ }^{25}$ could not enjoy the play's genuine force. But the reason for

${ }^{25}$ It was premièred in Madrid, at the Infanta Beatriz, on 19 December 1929. 
this did not lie exclusively in the nature of the text which was utilized but rather in the poor performance of the actors. The play was not completely void of satirical force, in spite of the cuts made by the translators. But the actors were not allowed enough time to offer a satisfactory performance. ${ }^{26}$ The time of rehearsal was so short that they could not even learn their lines, much less discover the type of approach most suitable for their characters. The reason for this shortage of time was none other than a fierce competition to stage the play in Spain before other rival companies did. The success of Romains' version in France and elsewhere had resulted in the simultaneous rehearsal of three different versions of Volpone, but none of them gave a satisfactory performance as too much was left to improvisation. ${ }^{27}$

\section{Dullin's anti-naturalistic performance}

As the Paris correspondent of The Times fittingly observed, Dullin's 1928 production of Romains' version at the Atelier produced "that sense of simultaneous exhilaration and satisfaction that only a perfect attunement of the literary and visual factors can give" (1929). He highlighted the importance of Director Charles Dullin who, like all the members of the Cartel des Quatre, "attempted to allow full scope to all the elements in a play, to achieve a real harmony of word and acting and action."

Like the other members of the Cartel, Charles Dullin took up Copeau's scenic reform, and, as Walter Volbach aptly concludes, "demonstrated that modern theatre needs no elaborate realistic scenery [...] but an ensemble of performers trained and so rehearsed that they live the characters and project the inner meanings of the plays" (1965: 213-214; my italics). This is, no doubt, what Dullin achieved in his production of Volpone, although it certainly was no easy task, as his friend and co-founder of the Cartel, Louis Jouvet, realized when he

\footnotetext{
${ }^{26}$ If reviews are to be trusted, neither were the leading characters in a proper command of their roles, nor was the sprightly rhythm of Romains's version taken advantage of. According to "Floridor", "Los artistas del Infanta Beatriz [...] no 'entraron' en sus respectivas figuraciones" (1929: 33), and, in E. Díez Canedo's view, "unos actores que aún no se habían aprendido sus papeles fueron arrastrando hasta el final de los cinco actos" (1929: 3).

${ }^{27}$ For a more detailed explanation, see Ribes (2005: 82-89).
} 
agreed to direct the production. Initially, he was also going to play the leading part, but he gave up after several months because he found the role too complex. ${ }^{28}$ Dullin then took over, but it is obvious that he did not improvise, since the comedy was not premièred until eight months later. There probably is no better account of how demanding it is for an actor to play the part of Volpone than Marquetty's report on Jouvet's deepest convictions:

Le personnage de Volpone est un personnage qui exige tout ensemble de la roverie et de la force, du charme et un certaine perversité. Il tient la scène d'un bout à l'autre du drame. Il ne laisse acun repos et demande à être nuancé presque à chaque réplique. (1952: 121; my italics)

Dullin, too, must have been well aware of Volpone's elusive nature, as he shows in his Souvenirs et notes de travail d'un acteur, where he explains how hard he tried to discover his character for years:

Je l'ai retrouvé au cours de la vie et de mes voyages [...] Cet insaisissable Volpone changeait souvent de visage [...] le plus souvent il avait sa barbiche fin d'oriental, se détachant sur le visage maigre [...] un peu bilieux, arrogant ou servile [...] mais toujours avec son oeil aigu de voyeur d'âme et sa pelisse fourrée lui donnant une allure de renard argenté. (1946: 44; quoted in Henry 1960: 201; my italics)

His report reveals the influence of Stanislavsky's techniques. But, as he also explains in his Souvenirs, he was aware of the importance of self-control, which could only be achieved through disciplined practice (Dullin 1999 (1946): 394-395). His successful performance of Volpone was, no doubt, the result of his technical prowess, as Titayna (1929: 48) underlines when emphasizing that Dullin was "excelent en tant que technique," to the point of looking like "un acteur froid."

But few reviews are as illuminating as D'Houville's for us to understand how effectively Dullin nuanced the role of Volpone. He describes him as

Tour à tour gémissant d'une voix mourante [...] geignant, faible et doux, ou violent, reuscité, fluirant voluptueusement l'odeur de la

\footnotetext{
${ }^{28}$ And, as Paul Hahn highlights, Jouvet's greatest belief was "in the supremacy of the playwright" (1951: 345).
} 
richesse et $\mathrm{du}$ mesonge démoniaque, caressant, railleur, orgeuilleux, ou humille. (1928: 2)

J. Kessel's review also draws attention to Dullin's technical excellence when he points to his diction and movements: “C'est $\mathrm{M}$. Charles Dullin qui donne à Volpone ses mouvements félins et sa diction cruelle" (1928).

As different accounts of the production show, the performance of the whole cast was highly satisfactory, since all the actors paid due attention to gesture, movement, range of voice, diction and intonation. D'Houville's detailed description of Corbaccio, as played by M.G. Seroff, also highlights his command of the part. He presents him as "hideux, centenaire, hailloneux, convulsé, tremblant son corps, son costume, sa voix, ses gestes, ses intonations, ses regards, ses mots, qui havent sont d'une inoubliable horreur" (1928: 2).

His depiction of Daniel Lecourtois' enactment of Mosca is no less revealing of his thorough training as actor:

Daniel Lecourtois joue le rôle difficile de ce Mosca, rôle de fourberie froide, impitoyable, où les tours de passe passe sont d'une ampleur telle que l'horrible y rejoint le burlesque. (D'Houville 1928: 2)

In all three cases, D'Houville shows unreserved admiration for the actors' ability to express horror. ${ }^{29}$ However, he reduces its intensity by making clear that it is not expressed in a realistic way but by means of comic exaggeration, which he defines as burlesque. D'Houville's observation is in keeping with René Salomé's appraisal of the actors' performing style. In his view, Volpone is "un personnage d'une réalité impérieuse, en dépit de tares grossies jusqu'à la caricature" and he adds: "pareils grossissements frappent chez Voltore, Corvino et Corbaccio" (1929: 344; my italics). This is the same impression which Ceria, from $A B C$, received at the Paris première. The Spanish reviewer made the following assessment of Volpone: "La adaptación que acabamos de ver en el Atelier [...] es una tremenda sátira burlesca de la Humanidad arrodillada ante el poder del oro" (1928: 37; my italics).

${ }^{29}$ Davin de Champclos' description of Leone as performed by Ph. Role in Nice in November 1930 draws attention to the same features when he mentions the actors' "silhouette massive et verbe truculent" (1930). 
When advertising the play, Baret's Touring Company similarly spoke of "cette farce otrée, jusqu'a devenir tragique" (Playbill 1929a), which, again, drew attention to the anti-naturalistic style which had been chosen to express its tragic subject matter. This rejection of naturalism had presided over Dullin's productions, in the same way as it had guided his predecessor Copeau and the performances of the Cartel des Quatre. It was the guiding principle which had determined their choice of set and stage props, which were always kept to a minimum so as to focus attention on the performers. ${ }^{30}$ Charles Dullin therefore underlined the usefulness of Barsacq's "décor unique" for the second act because it directed the spectator's attention to the text: ${ }^{11}$ "En faisant le décor unique du deuxième acte [...] on ne s'ocupe plus que du texte " $32^{2}$ (my italics).

Simple stage elements like a staircase could reinforce the significance of the text, as D'Houville's description of its use by actors at the end of the play makes clear: "[Volpone] disparaît dans l'escalier par où montaient les êtres atroces qu'il se plaisant à rendre encore plus vils" (1928: 2). This detailed picture of a defeated Volpone going down the stairs towards his exile while his greedy suitors go up to celebrate his "death" visually underlines the changing nature of Fortune in a world controlled by avarice. D'Houville's shrewd observation regarding the moral nature of the characters speaks of the ability of players to stage it. In his view, greedy characters do not improve their nature but become more despicable as the play advances. The possibility of inheriting Volpone's wealth awakens their basest instincts, which are not changed in spite of Volpone's apparent death. Their attitude towards Mosca, who has inherited everything, is as contemptible as before. It is him that they end up flattering. As a result, the tone is not cheerful but realistic. Through the magnifying lens of caricature it shows the

\footnotetext{
${ }^{30}$ For D'Houville, "la suppression d'un intérieur trop réaliste [...] entraine le spectateur à concentrer toute son attention sur le texte, le jeu et la silhouette de l'acteur, sur l'expression juste des sentiments, en un mot sur l'essentiel" (D'Houville 1928: 2). His assessment, however, sounds so much like Dullin's own words because he was quoting him without acknowledging his source (Correspondance 10, Nov. 1929).

${ }^{31}$ This performing style, of course, was not suitable for every kind of text, but, as A.B. points out, "Il faut q'un texte soit puissant, généreux, que l'action rebondisse, captivante et fournie, pour se paser de tout l'apparat des accessoires" (1930).

${ }^{32}$ Rony highlights that this simple setting had "plusieurs lieux évoqués en un même space simultané" (1993: 347).
} 
gullibility of greedy characters who are deluded by their own avarice. Their covetousness, in spite of all their wit, renders them unable to learn from experience and improve their behaviour.

This crude picture of human nature is so humorously portrayed that the comedy achieves the difficult task of conveying a moral message while, at the same time, delighting the audience. This may have been Jonson's aim, too. Romains' happy ending allows for an ambiguous and ironic presentation of universal greed. The absence of strict rules regarding poetic justice lends this satirical comedy greater subtlety since no single reading is imposed on an audience allowed to draw its own conclusions. Spectators can enjoy the malicious resourcefulness of the characters while simultaneously realizing the degrading effects of avarice.

As the analysis of different reactions to the play has shown, Romains rediscovered Volpone for twentieth-century spectators and gave the play a new validity by offering a perfect synthesis of "la force comique du sujet et l'âpre signification de la pièce" (Les AvantPremières 8.11.1930; my italics). His version, moreover, was perfectly calculated for professional ensembles like Dullin's or Barrault's to make it fully meaningful to their audiences.

\section{References}

A.B. 1930. "Les décors de 'Volpone' au Grand-Théâtre." Vie Bordelaise 4.3.1930.

"Au Théâtre Flamand." L'Indépendance Belge, 16.2.1930.

B. 1926. "Theater, Kunst und Musik. Burgtheater. Volpone. Eine lieblose Komödie von Ben Jonson. Frei bearbeitet von Stefan Zweig." Reichpost 7.11.1926.

Barbour, Thomas 1957. "Revivals and Revisions: Theatre Chronicle." Hudson Review 10/2: 261-262.

Bellotti, Mario 1929. “La Comédie de Volpone." Comedia 14.12.1929.

Bidou, Henry 1929. "La Semaine Dramatique." Feuilleton du Journal des Débats 26.8.1929.

Boquet, G. 1991. "Romains' Volpone." Cahiers Élisabethains 40: 112-114.

“Bordeaux. La Saison de Printemps. Creation de Volpone." Comedia 27.4.1930.

Calvo, Luis 1930. “La visita de Volpone." La Nación, Marzo 1930.

Ceria 1928. "ABC en París. Estreno de Volpone." ABC, 24.11.1928: 37. 
Copeau, Jacques 1974 (1913) “Un essai de rénovation dramatique." Eds. Marie-Helène Dasté and Suzanne Maistre Saint Denis. Appels. Registres. Paris: Gallimard: 25-32.

D’Amico, Silvio 1930. "Volpone all'Argentina." Tribuna 7.2.1930.

Davin de Champclos, Gabriel 1930. "Palais de la Méditerranée. Volpone, pièce en cinq actes, de MM. Jules Romains et S. Zweig." Éclaireur 24.11.1930.

D’Houville, Gérard 1928. “Chronique Dramatique du Figaro: Théatre de l'Atelier: Volpone, comédie en 5 actes d'après Ben Jonson, par Stefan Zweig et Jules Romains." Le Figaro 3.12.1928: 2.

Díez Canedo, Enrique 1929. El Sol 21.12.1929: 3.

Dorgelès, Roland 1923. Le Réveil des Morts. Paris: Albin Michel.

Dullin, Charles 1999 (1946). "Recuerdos y notas de trabajo de un actor (Souvenirs et notes de travail d'un acteur)." Ed. José A. Sánchez. La escena moderna. Manifiestos y textos sobre teatro de la época de las vanguardias. Madrid: Akal: 386-396.

Felusich, Mirto 1926. "Kunst und Wissenschaft. Burgtheater. Zum ersten Mal: Volpone, eine lieblose Komödie nach Ben Jonson, frei bearbeitet von Stefan Zweig." Österreichische Tageszeitung 7.11.1926.

Floridor 1929. $A B C$ 20.12.1929: 33.

Forsyth, Karen 1981. "Stefan Zweig's Adaptation of Jonson." Modern Language Review 76: 619-628.

Frank, Paul 1926. "Burgtheater. Stefan Zweig: Ben Jonsons Volpone: eine lieblose Komödie." Theaterzeitung 7.11.1926.

G.R. 1929. "Volpone. Au Théâtre du Parc de Bruxelles." Indépendance Belge 28.12.1929.

Gassner, John 1957. "Broadway in Review." Educational Theatre Journal 9/1: 118.

Genette, Gerard 1982. Palimpsestes, la littérature au second degré. Paris: Editions du Seuil.

Genette, Gerard 1987. Seuils. Paris: Seuil Poétique.

Griffith, Malcolm 1970. "Theatre in Review. Volpone. By Ben Jonson. Seattle Repertory Theatre. Seattle. November 1969." Educational Theatre Journal 22/1: 106-107.

Hahn, Paul 1951. "Louis Jouvet 1891-1951." Educational Theatre Journal 3/4: 345-346.

Henry, Hélène 1960. "Charles Dullin et le théâtre Elisabéthain." Études Anglaises 13: 197-204. 
Herford, C.H. \& Percy \& Evelyn Simpson 1925-1952. Ben Jonson IX. Oxford: Clarendon Press, 11 vols.

Jaloux, Edmond 1928. “Les Alchimistes." Le Temps 28.12.1928.

Jaloux, Edmond 1931. “Chronique. L'Auteur de Volpone." Le Temps 4.12.1931.

Jauss, Hans Robert 1970. Literaturgeschichte als Provokation der Literaturwissenschaft. Frankfurt: Suhrkamp.

Joannis, Jean 1930. "Volpone III." Chantecler 18.1.1930.

Kessel, J. 1928. "Volpone à l'Atelier." Gringoire 30.11.1928.

Langner, Ruth 1928. Ben Jonson's Volpone, A Loveless Comedy in Three Acts. Freely Adapted by Stefan Zweig and Translated from the German by Ruth Langner. New York: The Viking Press.

“Les Avant-Premières. Palais de la Méditerranée. Création à Nice de Volpone, pièce en 3 actes d'après Ben Jonson, adaptée par M.J. Romains et S. Zweig, musique de G. Auri." Éclaireur 8.1.1930.

“Les Avant-Premières. Palais de la Méditerranée. Création à Nice de Volpone, pièce en 3 actes d'après Ben Jonson, adaptée par M.J. Romains et S. Zweig, musique de G. Auri.“ Éclaireur 22.11.1930.

Lyons, Charles R. 1967. "La Compagnie Madeleine Renaud- Jean Louis Barrault: The Idea and the Aesthetic." Educational Theatre Journal 19/4: 415-424.

Marquetty, Valentin 1952. Mon Ami Jouvet. Paris: Ed. Du Conquistador.

McPherson, Donald 1973. "Rough Beast into Tame Fox: the Adaptations of Volpone." Studies in the Literary Imagination 6/1: 77-84.

Muller, Carlos ed. 1929. Programme de les Tournées Ch. Baret. Société Janvier, Audier \& Cie. Volpone. Comédie en 5 actes d'après Ben Jonson par Stéphan Zweig et Jules Romains. Paris: Rue du Rocher, 1929-1930; 1930-1931.

Nouschi, Marc 1996. Historia del Siglo XX. Todos los mundos, el mundo. Madrid: Cátedra.

"Palais de la Méditerranée. Création de Volpone, 5 actes de Ben Jonson, adaptées par MM. Jules Romain et S. Zweig." Éclaireur 10.1.1930.

Paris Correspondent 1929. “Entertainments. The Paris Theatre. Ben Jonson's Volpone." Times 11.2.1929.

Playbill. Tournées Ch. Baret 1929a. Volpone. Pau, Casino-Palace, 2.9.1929.

Playbill. Tournées Ch. Baret 1929b. Volpone. Limoges, Theatre Municipal, 19.11.1929.

Playbill. Tournées Ch. Baret 1930a. Volpone. Beauvais, Theatre Municipal, 19.4.1930. 
Playbill. Tournées Ch. Baret 1930b. Volpone. Le Tréport. Casino Municipal, 4.8.1930.

Precioso, Artemio and Rafael Sánchez Guerra 1930. Volpone. Comedia en cinco actos, arreglada por Stefan Zweig y Jules Romains. Madrid: Colón.

Programme pour Volpone. Comédie en 5 actes, d'après Ben Jonson, par Stefan Zweig et Jules Romains. Direction Ch. Dullin. Théâtre de l'Atelier, 23.11.1928; 3.11.1929.

Programme pour Volpone. Au Théâtre du Parc de Bruxelles 28.12.1929.

Ribes Traver, Purificación 2005. "Araquistáin's 1929 Version of Volpone." Sederi 15: 81-101.

Ribes Traver, Purificación 2006. "Spanish Adaptations of Ben Jonson's Volpone." Ed. José Manuel González Fernández de Sevilla. Spanish Studies in Shakespeare and His Contemporaries. Newark: University of Delaware Press: 262-298.

Ribes Traver, Purificación 2007. "Stefan Zweig's Volpone, eine lieblose Komödie on Stage in Austria and Germany (1926-1927)." The Ben Jonson Journal 14/1: 61-78.

Romains, Jules 1928a. Volpone. En collaboration avec Stefan Zweig d'après Ben Jonson. Paris: Les Oeuvres Libres.

Romains, Jules 1928b. “Avant-Première." Paris-Soir 23.11.1928.

Romains, Jules \& Stefan Zweig 1950. Volpone. Paris: Gallimard.

Rony, Oliver 1993. Jules Romains ou l'appel au monde. Paris: Éditions Robert Laffont.

Salomé, René 1929. "Chronique Dramatique. Volpone. Départs." Études 5.2.1929: 342-345.

Savage Brosnan, Catharine 2005. "French writing of the Great War." Ed. Vincent Sherry. The Cambridge Companion to the Literature of the First World War. Cambridge: Cambridge University Press: 166-190.

Steinberg, Michael P. 2000 (1990). Austria as Theatre and Ideology. The Meaning of the Salzburg Festival. Ithaca and London: Cornell University Press.

Titanya 1929. Bonjour la Terre. Paris: Éditions Louis Querelle.

Volbach, Walter R. 1965. "Jacques Copeau, Appia's Finest Disciple." Educational Theatre Journal 17/3: 206-214.

Watson, Peter 2002 (2000). Historia intelectual del siglo XX (A Terrible Beauty. A History of the People and Ideas that Shaped the Modern Mind). Trans. David León Gómez. Barcelona: Crítica.

Wittner, Victor 1927. “Wiener Schauspielabend." Das Theater 8/1: 20-22. 
P. Ribes Traver

Zweig, Stefan 1926a. Volpone. Eine Lieblose Komödie in drei Akten von Ben Jonson. Frei bearbeitet von Stefan Zweig. Berlin-Wilmersdorf: Felix Bloch Erben.

Zweig, Stefan 1926b. Ben Jonsons Volpone: eine lieblose Komödie in drei Akten. Potsdam: Kiepenheuer Verlag.

Zweig, Stefan 2007 (1942). Die Welt von Gestern. Erinnerungen eines Europäers. Frankfurt am Main: Fischer Taschenbuch Verlag.

How to cite this article:

Ribes Traver, Purificación. "The early stage history of Jules Romains' Volpone." SEDERI 19 (2009): 121-150.

Author's contact: Purificacion.Ribes@uv.es

Submission: 09/06/2008 Acceptance: 18/10/2008 